\title{
Demand-based Provision of Housing, Welfare and Care Services to Elderly Clients: From Policy to Daily Practice Through Operations Management
}

\author{
Carolien de Blok - Bert Meijboom • \\ Katrien Luijkx · Jos Schols
}

Published online: 19 July 2008

(C) The Author(s) 2008

\begin{abstract}
Practical implementation of notions such as patient-orientation, clientcentredness, and demand-driven care is far from straightforward in care and service supply to elderly clients living independently. This paper aims to provide preliminary insights into how it is possible to bridge the gap between policy intent, which reflects an increasing client orientation, and actual practice of care and service provision. Differences in personal objectives and characteristics generate different sets of needs among elderly clients that must have an appropriate response in the daily routines of care and service providers. From a study of the available literature and by conceptual reasoning, we identify several important operational implications of client-oriented care and service provision. To deal with these implications the authors turn to the field of operations management. This field has deepened the understanding of translating an organisation's policy into daily activities and working methods. More specifically, we elaborate on the concept of modularity, which stems from the field of operations management. With respect to elderly people who live independently, this concept, among others, seems to be particularly useful in providing options and variation in individual care and service packages. Based on our line of reasoning, we propose that modularity provides possibilities to enhance the provision of demand-based care and services.
\end{abstract}

C. de Blok $(\bowtie) \cdot$ B. Meijboom $\cdot$ K. Luijkx $\cdot$ J. Schols

Department of Tranzo, Tilburg University, P.O. Box 90153, 5000 LE Tilburg, The Netherlands

e-mail: s.a.deblok@uvt.nl

B. Meijboom

Department of Organisation and Strategy, Tilburg University, P.O. Box 90153,

5000 LE Tilburg, The Netherlands

J. Schols

Department of General Practice, Maastricht University, P.O. Box 616,

Maastricht $6200 \mathrm{MD}$, The Netherlands 
Furthermore, our findings offer direction on how organisations in housing, welfare and care can be guided in translating demand-based care to their operational processes.

Keywords Demand-based care · Elderly clients · Operational level · Operations management . The Netherlands

\section{Introduction}

In most Western countries the ageing society is a fact. In the Netherlands, for example, 20 years ago $12 \%$ of the population was 65 years or older. Nowadays, $14 \%$ is this age, and it is expected that in $2025,20 \%$ of the population will be 65 years or older [11]. The same trend can be seen in other counties of the European Union, Sweden and Italy having the largest aged populations [57]. During the past decades governments all over the developed world have been engaged in reforming their health care systems to cope with the challenges that are thrown up by their ageing populations [13]. Along with changes due to the size of elderly populations, we are also witnessing changes in the political orientation towards health care provision. Analogous to most European countries, the Dutch government is creating a health care system in which the client is given a more central position [e.g. 16, 45]. There are various terms used to describe this increasing consideration for health care clients, here we will define this trend as one towards demand-based care.

The modifications in the Dutch system, as in those of other countries, encourage suppliers of health care services to become more responsive towards the needs and desires of their elderly clients $[6,67]$ and to treat their demands as an entity that should be approached in a well-tuned manner [2]. In general, elderly people want to live independently as long as possible, even when they need care and support. As a result, the issues surrounding care provision are extensive, involving many aspects of life such as health, social services, housing, transportation, and support services [27, 64]. Ideally speaking, demand-based care provision would imply that organisations providing services in housing, welfare and care (HWC) should take conjointly the needs and demands of an individual elderly client as a guideline. However, little insight has been gained in how the needs of individual elderly clients can be translated into a demand-based, client-centred supply of HWC services [64]. The concept of demand-based care seems to falter at a policy level, being used by many to express long-term goals, mission statements and organisational visions only [46]. This is detrimental for all parties involved since a policy or strategy needs accompanying resources and methods for it to work in daily practice [60]. Fulfilling the multiple and complex needs of elderly clients requires organisations to develop sound operational processes in order to provide the optimal care and service packages to their clients. The aim of this paper, therefore, is to provide preliminary insights into how it could be possible to bridge the gap between policy intent, which reflects an increasing client orientation, and the actual practice of HWC service provision. To fulfil this aim, the following research question will be addressed by means of literature research and conceptual reasoning: 
How can demand-based care be brought into practice on the operational level of HWC provision to elderly clients living independently?

In order to answer the research question, the authors will turn to the field of operations management (OM). In general, OM has deepened the understanding of translating an organisation's policy or strategy into daily activities, processes and working methods. Furthermore, OM exhibits a natural client focus since operational systems are considered as means to serve the varying needs of an organisation's client [60].

\section{Demand-based Care}

\section{Definition}

As in most European countries, the Dutch sector for care for elderly persons exhibits a shift from supply-driven to demand-driven approaches in care and service provision. According to these approaches, care and related services in welfare and housing should contribute to the fulfilment of care-related needs of individual elderly people and, therefore, to their perceived quality of life [46]. In the Netherlands, this trend is known as being one towards demand-driven care (DDC) and demand-oriented care (DOC) [e.g. 44, 46]. Other concepts that can be found in international literature are 'consumer driven health care' [21], 'patient/client centred care' [e.g. 38, 39], 'patient/client oriented care' [59], etc. Although differences can be seen among the approaches, in terms of their specific emphasis and degree of client-centeredness [5, 46], all developments represent a client perspective on care and service provision. We will define this general trend, which takes client demand as the basis for care and service provision, as one towards demand-based care, where 'care' encompasses services in housing and welfare as well. As such, we acknowledge the importance of the client's central role. However, for the purpose of this paper, it is not relevant to go into a detailed discussion on the different emphases of all terms used.

The concept of demand-based care aims to give individual needs and wishes a more central role. As opposed to supply-driven approaches, where existing supply is the point of departure for care and service provision, the individual user's wants and needs form the starting point in the demand-based approach [46]. To accommodate individual demand, however, it should be clear what exactly clients' needs are and what these needs imply [64] for the organisation. Therefore, we now address the characteristics of our target population's needs and subsequently translate these into implications for day-to-day care and service provision.

\section{Needs: Diverse and Subject to Change}

The concept of need generally refers to a condition characterised as 'some disturbance in health and well-being' [64]. An individual elderly client perceives a disturbance, or gap, when the individual's current state does not match the desired state in health and well-being. Intervention, then, is necessary to close or diminish 
this perceived gap. When the gap can be closed or diminished by services in housing, welfare and care, the individual elderly client is said to be in need of these services [30].

Although all needs for HWC services exist because of some perceived gap or disturbance, the concept of need might vary considerably among elderly clients and can be transient and subject to change. First of all, variation is caused by differences in the current states of individual clients. An elderly client with diabetes has different needs from an elderly client who currently suffers from a broken hip. Even if two individuals have the same disability, they might perceive different needs [64]. Elderly clients vary a good deal with regard to their health definitions, preferences, desires and priorities [75]. These aspects will all influence the determination of the desired state or goal an individual elderly client wants to reach, and this makes the goal in health and well-being highly personal [32]. For example, an elderly client who is recovering from a stroke has always been accustomed to clean her house herself. Therefore, she might feel it is very desirable to work towards a state of health in which she will be able to clean her house again. During rehabilitation she needs her care professionals to support this goal by means of physical therapy, for example. If she cannot recover fully, this elderly client will need help at home, where the domestic help will take over the heavy household work. Furthermore, the domestic help worker might assist the client herself to do some light household activities, such as dusting. Another elderly client who is also recovering from a stroke is used to contract out all cleaning activities: regardless of this lady's state of health, the house is cleaned every week by a private cleaning lady. This client, therefore, perceives no need in this particular aspect of her life and might feel that it is much more important to focus on other aspects during rehabilitation. To reach the goals of these two individuals, and close the gaps between their similar current states but dissimilar desired states, different services in housing, welfare and care are needed. The need for care and related services, therefore, is highly personal [31], since it depends on the perspective of the individual [32, 47]. As such, great variety in needs for HWC services can be expected among elderly clients living independently.

Furthermore, the needs of an individual elderly client are changeable. Needs might alter over time both as a result of changing health conditions, which could either deteriorate or improve, and developments in knowledge [64]. These developments might alter either the current state of health and well-being, or the desired state. When the perceived gap between the current and desired state diminishes, manifest needs might disappear; when it increases, latent needs might become manifest. In both cases, manifest needs might change in content, breadth or depth. For example, an elderly client who currently has problems with bending or stretching needs some assistance in the morning when taking a shower. Over time, his condition might deteriorate, and as a result, he will need support when getting out of bed and total assistance when taking a shower.

Both variety among elderly people and variation over the life course of an individual elderly person cause a high diversity on the demand side of HWC services. This will have implications for the supply side of HWC services, when organisations aim to provide their care and services in a demand-based manner. 
Conversion to Daily Practice: Implications for Providers

The concept of demand-based care stimulates providers of care and related services to be sensitive to the diversity in needs. However, the provision of a care and service package that is exactly in line with each individual client's preferences is not feasible for most care and service providers. Instead, organisations look for broader classes of clients, or segments, that can be reached more efficiently with options that match their unique needs [24], also with respect to independently living elderly clients, segments have been identified [35-37]. Within these segments, elderly clients have similar needs and requirements that differ substantially from the needs of elderly clients in another segment. At the same time, the needs of individual elderly clients within a particular segment might show a slight diversity [12, 35]. Over time, the needs of an individual elderly client might change, which might even cause a shift from one segment to another.

An organisation that adapts its supply to segments recognises that clients differ in their needs and perceptions [24]. For each segment of elderly people, a generic package of HWC services can be identified that matches the needs profile of this segment. However, due to the differences amongst individuals within a segment, this generic package requires further specification and its contents need finetuning [35]. On the supply-side, services in housing, welfare and care can be better tuned to the diversity in needs when the available range of options in service supply increases [e.g. 16, 73, 75]. Only then will clients be able to fulfil their needs with care and services of their preference, given their personal background, taste and circumstances. Choice options within a certain type of service are required to provide an optimal solution per individual. When alternatives are offered, elderly clients themselves, as much as possible and as far as they desire to avail themselves of the options, can select those that are best suited to their needs [16].

In addition, the set-up of the care and service packages should be flexible. As well as choice options in the individual types of care and services needed, variation has to be enabled when combining different categories of services into a single package. Variation will allow for diversified care and service packages among elderly clients. Moreover, variation in HWC services is needed over the life course of an individual elderly client. Depending on the current state of health and wellbeing of the individual client, needs arise in order to enable him or her to stay in his or her own living environment as long as possible. However, this situation changes over time, mostly due to deteriorating health, and therefore adaptation and expansion in the nature, amount, and intensity of care and services will be required at different points in time.

Furthermore, to continuously provide the optimal answer to the needs of an individual, organisations have to interact regularly with the elderly client. Clients value being involved in the care process, being taken seriously and being consulted in the determination of their needs for care and services [48] with respect to their goals and preferences. As such, an organisation providing HWC services should arrange its care and service processes in such a way that they explicitly and adequately cater to the needs and requirements of elderly clients [68]. 
Finally, when examining an elderly client's needs for housing, welfare and (long term) care, organisations often tend to make strict distinctions between these main pillars of care and service provision [10]. However, for an individual elderly client, these services are interrelated since they all enable an elderly person to continue to live independently as long as possible. Therefore, when taking client demand as the basis for care and service provision, HWC services need to be provided as an integral and coherent package. For providers, this implies they jointly have to deliver an optimal package of HWC services as an integral answer to the multiple needs of their elderly clients.

To sum up, a variety of needs exist among elderly clients and over the life course of an individual. To both recognise and manage this diversity, segmentation of the elderly population can be of help. Furthermore, to fulfil an individual elderly client's needs in a demand-based manner requires organisations to develop choice options and variety, and joint provision of HWC services. In addition, organisations should interact with elderly clients in order to determine their individual needs and wants, and be able to act upon them. Having determined several important implications of demand-based care on the operational level, it is time to look for principles and practices that will help HWC providers in dealing with these specifics. We turn therefore, to the field of OM; this field specifically addresses the organisational level where goods and services are actually delivered to the client. To get an idea of its contents, we will give a general introduction to OM in the next section.

\section{Operations Management}

Operations management $(\mathrm{OM})$ covers a body of knowledge that focuses on the design, functioning and improvement of a firm's operations function, where the term 'operations' refers to the use of resources, e.g. capital, materials, technology, human skills and knowledge, for the production and delivery of products, which can be either goods or services [53]. According to Slack et al. [60] the operations function is one of the three core functions of any organisation, along with the marketing and sales function and the product development function. The former is responsible for communicating the firm's products to the market; the latter for creating goods and services for the market. The operations function comprises all the activities that are involved in the transformation of inputs into outputs, thereby realising the products that are the reason for the organisation's existence. As such, the operations function is responsible for fulfilling customer requests throughout the production and delivery of goods and services [60]. Some examples of topics that have been widely researched in this respect are scheduling and sequencing of processes, workflow management, inventory control and performance measurement.

Besides constituting a natural client focus, OM goes beyond an organisation's strategic level by transferring the aim of an organisation into accompanying resources and methods to work in daily practice. An organisation can adapt or rearrange its operational processes or the operational organisation of products with the aim of reaching the goals of its customers as well as the performance goals of the organisation itself [e.g. $4,43,78]$. In the day-to-day production and delivery of 
products, common operational objectives are quality, cost, flexibility, speed and reliability.

\section{Operations Management in Services}

OM studies both manufacturing organisations, producing goods such as vehicles, canned food and clothing, and service organisations, producing services such as insurance, entertainment and health care. The main distinction between goods and services is the indispensable involvement of the client in service supply $[15,33,50]$. The participation of the client in the service production process will influence the whole process of service provision, from specification of the desired services to actual service delivery. Therefore, it is not only important what is being delivered to the client, for example a quick, cheap meal at a fast-food take-away or an exclusive haute cuisine dinner at a five star restaurant, but also how the service is being delivered, for instance, how the service professional treats the client and how the client is involved in service production. The service product and service process are two complementary and intertwined elements in final service provision [23, 69]. Other service characteristics that typically influence the design, functioning and improvement of service systems and processes are simultaneity of production and consumption, heterogeneity, perishability and intangibility [17].

In order to address the operational challenges of service organisations, the field of service operations management emerged. Like OM in manufacturing operations, service operations management constitutes designing, operating and improving the productive systems of the organisation [77]. On the one hand, service operations management covers principles that were traditionally developed for manufacturing, thus stemming directly from OM [see, for example, 12, 7, 41]. On the other hand, concepts, tools and techniques have been specifically developed for the field of service operations [see, for example, 28, 34, 43, 78]. Service operations management research has covered a wide variety of services in the profit sector, such as financial, restaurant and airline services. Furthermore, there is a growing realisation that service operations management may be relevant to changes in public and non-profit sectors in general $[70,71]$ and the health care sector in particular [e.g. $3,4,22,76]$. Examples in health care settings can be found primarily in hospital care [72], in particular in the development of clinical pathways [e.g. 8, 26] and focused clinical factories [e.g. 20, 29]. However, these examples are useful mainly for narrowly defined, homogeneous, client groups, suffering from only one or very few ailments, thereby having a predictable course of action in their care trajectory. Conversely, elderly clients usually have widely varying needs and wants, requiring a package of goods and services from several fields and specialisations to support their lives.

Although literature that specifically addresses the joint provision of demandbased care and service packages on the operational level is scarce, the application of service operations management has shown its ability to address client-centeredness for the non-profit sector in general. In order to meet new requirements on their demand sides, non-profit organisations focus on increasing flexibility and producing high-quality goods and services through the implementation of service operations 
management techniques and practices. A notable example of this is the research of Schellekens [53] who applied concepts originating from OM in the non-profit context of higher professional education.

The above shows the possibilities of service operations management to make the provision of non-profit goods or services more client-centred. This makes it useful to explore further service operations management focusing on the field of HWC service provision to elderly people living independently. The focus of concepts that stem from $\mathrm{OM}$ on the delivery of customer value might give new insights in and effective responses to the issues faced by HWC service organisations. Furthermore, the fact that services are different from goods and the understanding that in service provision both product and process need to be taken into account are important starting points for shaping demand-based care. These insights will be further explored in the next section, where we discuss specific $\mathrm{OM}$ principles in order to address the operational implications of demand-based care.

\section{The Client at the Centre of Interest on the Operational Level}

A number of researchers suggest that modularity is the key to providing tailor-made products while at the same time working in a cost effective manner [14]. Modular production principles traditionally stem from a manufacturing setting and, as such, have not been specifically developed for services. However, the attention given to modularity in services increases [e.g. 4, 42], with the aim of providing service packages that are tuned specifically to the requirements of the individual client. In this section, we will elaborate on the OM concept of modular production principles. Furthermore, we will argue that in services, modularity will have to be supported by conditions that take into account the specifics of services.

\section{Modular Production Principles}

In one of the first contributions to the literature on modular production, Starr [62] formulates the basic idea behind modularity as "... design, develop, and produce [...] parts which can be combined in the maximum number of ways". The seamless combination of parts that is referred to is allowed by the specific architecture of modular products. A product architecture is the scheme by which the functionalities of a product are assigned to product parts, or components [63]. A modular product architecture includes a one-to-one mapping of functional elements to physical components [18]. This means that each component, independently and separately from the other components, brings about one function of the product. The components of a modular product are standardised, so they are always produced in the same manner. To connect the separate, standardised components, and create a flexible product construction, a modular product architecture uses standardised connections, or interfaces [52].

In essence, literature suggests that modular production can facilitate the enlargement of the number of product features available, while at the same time preventing a rise in costs [14]. Since components can be easily mixed and matched through uniform 
interfaces, numerous combinations can be assembled that offer increased choice options to the organisation's clients [49]. Furthermore, the individual components included in a product can be changed or replaced independently, because each component has a separate function. Therefore, product distinctions can be easily achieved through transformation or modification of components [14]. In addition, modular production principles allow variations of goods and services to be delivered by different organisations [1,63], which again enlarges choice options for clients. All these features make modularity a good way to increase product variety [e.g. 63]. At the same time its use enables an organisation to produce at no significant increase in cost [62]. The utilisation of standard components reduces variety when making these components, which allows for cheaper production. In addition, when the standard components can be reused in products that appeal to different clients or client groups, economies of scale can be gained [63].

Modular production principles have been widely adopted in industry, for example in car manufacturing and construction. Besides, the application of modularity has also been suggested for optimising the marketing process [51], financial services [42], and hospital care [4] in order to arrive at customised service provision at reasonable cost.

The above clearly shows the potential advantages of the application of modular production principles. However, the presented overview of modularity is based mainly on its application in manufacturing organisations. In order for modularity to work properly in a service setting where client demand is central, we propose that certain prerequisites and conditions need to be present. In general, to enable individual client demand to have a more central role, it is a prerequisite that the client participates in the service process to a certain extent $[14,23,55,74]$. On the operational level this means that the system should be designed in such a way that service provider and client can be brought together to gear supply to client demand $[58,66,74]$. We will turn to this issue in the next sub-section.

\section{Supporting Conditions for Modularity in a Service Setting}

In the operational process, arrangements can be designed to allow for more or less client involvement. Front office activities take place in the presence of the client and allow for customising or personalising a service, and for involving the client as coproducer. Back office tasks, on the other hand, occur behind the scenes and have an efficiency potential [e.g. 25, 40]. To support considered choices and overcome tradeoffs among the advantages desired, Zomerdijk [77] has put forth design decisions accompanied by performance objectives regarding front office and back office configurations. For example, by choosing a certain configuration, or division and assignment, of front office and back office activities, an organisation will be able to design an operational process that allows for both client involvement and efficiency [77].

In addition, issues regarding the professional providing the service also need to be addressed. As opposed to the production of goods, service production, delivery, and consumption generally take place simultaneously. Especially in human service 
organisations, which are organisations that work directly with and on people, all essential tasks are carried out by a series of transactions between clients and staff [19]. Therefore, a client's perception of the service largely depends on the quality of the professional, besides the quality of the service itself $[43,56]$. The composition of service packages is therefore greatly dependent upon the employee involved in the service process, who thereby forms the linking pin within the service package. As such, service employees function as human interfaces: they have the ability to influence the care and service product as well as the way in which this is provided.

\section{Discussion}

In this paper we argued that the notion of demand-based care has not yet been elaborated to the operational level of HWC service providers. Demand-based care implies that client demand is taken as the leading aspect in the daily activities and routines of HWC service providers, concerning care and service provision. In this section, we will discuss the implications of demand-based HWC service provision to elderly clients in the light of modularity and its supporting conditions.

\section{Modularity Versus Four Implications of Demand-based Care}

On the basis of our concise review, modular production principles provide a useful starting point for providing demand-based HWC services. A modular design of HWC services offers the opportunity to mix-and-match components into a tailormade care and service package for elderly clients. The design and operational organisation of the individual care and service components are such that they can be combined in numerous ways. As such, modular care and service components will provide choice options and variation for the elderly client. Since every elderly client can be offered a different combination of components, each is treated as unique [4], which is the aim of demand-based care provision. For example, a client who has problems with bending and stretching will likely require components that provide assistance in such functionalities as 'cleaning the house' and 'mobility', which are supplied by a certain HWC service provider. With respect to 'cleaning the house', components such as vacuum cleaning, window washing, dusting, mopping, etc., should be designed in such a way that they can be selected and mixed in any combination desired. The components of 'cleaning the house' can be blended into the client's care and service package with components in 'mobility', such as a walking frame, rollator or scooter for the disabled. This implies that not only the contents but also, for example, the duration, location and executor of the components need to be specified exactly in advance, and adjusted in such a way that they can be easily combined for or by an individual client.

Furthermore, service parts may well originate from multiple providers and then be put together into one HWC service package, thereby not only increasing choice options but also facilitating the coupled supply of a care and service package. For elderly clients, who often require care and services from several suppliers in various fields, this will increase the likelihood that all their needs and wants are covered. 
Elaborating on the earlier example, the client who has problems with bending and stretching might require the functionality 'domestic adaptations' as well, which is provided by a different HWC service provider. This functionality includes components such as a heightened toilet, the removal of thresholds and supplying support rails in the shower. Furthermore, this provider supplies other components in the functionalities 'cleaning the house' (such as spring-cleaning) and 'mobility' (such as a shared taxi service and taxi service with care), which the client might select as well. These additional components can be seamlessly combined in the individual care and service package because the modular package architecture uses standardised and well-tuned connections. Together, the combination of care and service components, which originally stem from different providers, provides an optimal answer to this client's requirements.

Approaching client needs and wants as an entity, as in the example, is expected to enhance the overall outcome of the HWC service provision for the client and provide services that are better attuned to the needs of an individual elderly client. Individual services can be coordinated in terms of, for example, time, place, content, condition, quality and price. This is likely to diminish overlap among individual HWC service parts as well as prevent gaps in HWC service provision from occurring, thereby enhancing continuity and complementarity of care and service provision. An additional advantage lies in the provision of the HWC service parts as a package, instead of each individually; this could greatly reduce the time and effort that elderly clients have to invest in searching for and keeping contact with HWC service providers. For providers, the package-wise provision of HWC services can also result in saving time during the intake, since all HWC services required by an elderly client can be identified at the same time. Furthermore, standardisation of the interfaces between components would be likely to facilitate tuning both within and among organisations.

The needs and wants of elderly clients will probably change over time, due to deteriorating or improving health. Modularity allows for easy adaptation of the HWC service package, because the individual components included in a package can be changed or replaced independently. When one component is omitted or added, the other components are not influenced by this and the package as a whole continues to function. This allows the HWC service providers to keep the care and service package up-to-date with relative ease so client demands will be met optimally over time.

So far, we have argued how modular production principles can help HWC service providers to put individual elderly client demands at the centre of service provision. At the same time, the ability to standardise components can also facilitate a cost-efficient way of working. Furthermore, it is likely that the content of a component will appeal to more than one client or client segment. Therefore, the conceptual design [61] of a certain care or service component can be reused, thereby yielding economies of scale. Although the efficiency potential is not specifically attached to demand-based care and service provision, it favours a goal of the Dutch care sector in general. Governmental policy can be characterised by efforts to introduce more business risks [9] in the care sector, thereby initiating the need for a cost containment in care and service provision. HWC providers are even encouraged 
to drive down their costs of operation [e.g. 65]. In working towards this goal, a modular set-up of components is likely to be helpful.

\section{Supporting Conditions for Modularity in HWC Provision}

To make optimal use of modular production principles HWC service providers not only need to pay attention to the composition and content of the care and service packages. To support the application of modularity, the processes and professionals involved in the specification of these packages need major consideration. In order to provide demand-based care and services, the information given by the elderly client should be the basis on which HWC service providers specify which care and service parts have to be combined into a package. The professionals who construct the demand-based care and service packages have to be able to retrieve client information, to translate this information, in collaboration with the client, into concrete needs and wants, and to link these to the care best suited and service parts available. To be able to take client needs and wants as the starting point of care and service provision, HWC service providers need to create a situation in which elderly clients can easily interact with professionals and express their requirements prior to the start of care and service delivery. Front office activities take place in direct contact with the client and offer the opportunity for interaction between the elderly client and the professional. In a front office setting, the elderly client therefore will have the opportunity to express his needs and wants to the HWC professional, who in turn can compose the care and service package in a customised or personalised manner in cooperation with the client. In front office activities, the client can also be a co-producer, for example, by letting the client him or herself fill out a questionnaire about required care and services. This will allow for greater client involvement in the construction of the care and service package. During delivery, HWC services work directly with or on elderly clients [19], and therefore, are by definition front office activities. This will facilitate on-going interaction between professional and client, thereby providing the opportunity to adapt the elderly client's care and service package when needed.

However, the elderly client does not have to be involved in all activities required to set up the appropriate care and service package. Some activities, such as administration of client data or checking the care and service package against financial regulations can take place behind the scenes. These, so-called, back office activities are suited for standardised processing of large amounts of data, thereby offering efficiency potential to the HWC service providers.

Overall, modular production principles will allow conceptually HWC service providers to put demand-based care into practice. Modularity seems to be particularly useful in providing choice options, variation and joint provision of care and service packages, whereas supporting front office-back office conditions seem to promote client interaction in HWC service supply. Furthermore, both concepts would avoid a rise in costs, something that is very desirable in HWC service provision.

The proposed applicability of modular production is based on the indirect assumption that, with all their diversity, elderly clients are still sufficiently alike for modularity to work. Although elderly clients all are unique individuals, we have 
already pointed out that overlap can be found in the needs and demands of elderly clients [35-37]. Besides, research has revealed packages in HWC service combinations that elderly clients actually acquire [54]. Because of these analogies among elderly clients, providers of HWC services can indeed make use of a modular set-up of care and services, at least for those categories of needs and wants that overlap within, or among, segments of the elderly population. Through seamless combination of standard components in packages, advantages in cost, time and quality can be gained [4]. The resources gained can, in turn, be deployed to those dimensions of needs which are too complex or distinctive to address with standardised modules and components. Modularity, thereby initiates blending of standard and custom care and service provision by addressing those dimensions in which groups of clients have the same needs with standardised components, while leaving room for the natural heterogeneity of elderly clients [4].

\section{Conclusion}

The previous sections have shown the ability of modular production principles to deal with the highly diverse needs of elderly clients, thereby enhancing the provision of demand-based HWC service packages. The concept enables approaching the operational implications of demand-based care and putting client demand at the centre of HWC service provision. As such, modularity, when properly adapted to a service setting, has high potential to close the gap between policy and practice that current literature on demand-based care has not been able to solve so far. The recognition of the potential of this concept is an important first step in elaborating demand-based care and service provision to the operational level. This makes our insights of significant relevance to both policy makers and practitioners.

Our findings, however, are largely based on theory, so highly conceptual in nature, and at this time can be supported merely on the basis of intuitive appeal and experience rather than by empirical research. This makes our application of modularity and front office-back office configurations in HWC service provision to elderly clients living independently simplified. Furthermore, we are aware that we have left out social aspects of demand-based care, such as having the right attitude towards and respect for the client. Although we recognise the importance of the relational and emotional characteristics of demand-based care, we chose to focus only on operational characteristics. However, we opened up a working language and point of departure for studying the elaboration of demand-based concepts in an HWC context. From this starting point, additional research needs to be executed, both conceptually and empirically in order to further close the gap between policy intent and the daily practice of demand-based care and service provision. In this sense, interesting questions for investigation could be:

- What are the optimal basis, scale, amount and level of detail for the development of components and modules in HWC services from a client point-of-view?

- How should the professional be included as an integral part of a modular care and service architecture? 
- What requirements need to be present in the operational organisation to ensure the HWC service package can be delivered at any time, in any place and in any combination demanded?

- And, when taking a general systems view, how to align the construction of HWC service packages with the Dutch HWC system's financing structure?

Addressing these research questions will provide useful theoretical guidance to advance practice and will ultimately lead to the provision of demand-based care and services in the daily routines of HWC service organisations.

Acknowledgements The authors thank the health care insurers CZ and VGZ and the Science Shop of Tilburg University for their support of this research

Open Access This article is distributed under the terms of the Creative Commons Attribution Noncommercial License which permits any noncommercial use, distribution, and reproduction in any medium, provided the original author(s) and source are credited.

\section{References}

1. Baldwin, C. Y., \& Clark, K. B. (1997). Managing in an age of modularity. Harvard Business Journal, 75(5), 84-93.

2. Billings, J., \& Leichsenring, K. (2005). Integrating health and social care services for older persons. Aldershot: Ashgate Publishing.

3. Boaden, R., Haywood, P., \& Nuttall, P. (2000). Operations management in hospitals-What is it and who does it? In R. Van Dierdonck \& A. Vereecke (Eds.), EurOMA Conference: Crossing borders and boundaries. The changing role of operations, Gent.

4. Bohmer, R. M. J. (2005). Medicine's service challenge: Blending custom and standard care. Health Care Management Review, 30(4), 322-330.

5. Bosman, R., Bours, G. J. J. W., Engels, J., \& De Witte, L. P. (2008). Client-centred care perceived by clients of two Dutch homecare agencies: A questionnaire survey. International Journal of Nursing Studies, 45(4), 518-525. doi:10.1016/j.ijnurstu.2006.12.002.

6. Bosselaar, J. H. (2005). A demand for 'On demand'? Demand based delivery of social provisions: conditions and risks. Unpublished doctoral thesis, Erasmus University, Rotterdam.

7. Bowen, D. E., \& Youngdahl, W. E. (1998). Lean service: In defense of a production-line approach. International Journal of Service Industry Management, 9(3), 207-225. doi:10.1108/095642398 10223510.

8. Bragato, L., \& Jacobs, K. (2003). Care pathways: The road to better health services? Journal of Health Organization and Management, 17(3), 164-180. doi:10.1108/14777260310480721.

9. Breedveld, E. J., Meijboom, B. R., \& de Roo, A. A. (2006). Labour supply in the home care industry: A case study in a Dutch region. Health Policy (Amsterdam), 76(2), 144-155. doi:10.1016/j.healthpol. 2005.05.007.

10. Brodsky, J., Habib, J., Hirschfeld, M., \& Siegel, B. (2002). Care of the frail elderly in developed and developing countries: The experience and the challenges. Aging Clinical and Experimental Research, 14(4), 279-286.

11. CBS. (2005). Statline databank. Voorburg/Den Haag: Centraal Bureau voor de Statistiek.

12. de Blok, C., Meijboom, B., Luijkx, K., \& Schols, J. (2007). Modularity in health care: Towards costefficient and client-focused service provision. In N. Acur, N. K. Erkip \& E. D. Gunes (Eds.), 14th EurOMA conference: Managing Operations in an expanding Europe, Ankara.

13. de Gooijer, W. (2007). Trends in EU health care systems. New York: Springer Science.

14. Duray, R., Ward, P. T., Milligan, G. W., \& Berry, W. L. (2000). Approaches to mass customization: configurations and empirical validation. Journal of Operations Management, 18, 605-625. doi: 10.1016/S0272-6963(00)00043-7. 
15. Edvardsson, B., Gustafsson, A., \& Roos, I. (2005). Service portraits in service research: A critical research. International Journal of Service Industry Management, 16(1), 107-121. doi:10.1108/ 09564230510587177.

16. Etty, W. (2000). De ontvoogding van de AWBZ. The Hague: Ministerie van VWS.

17. Fitzsimmons, J. A., \& Fitzsimmons, M. J. (2006). Service Management: Operations, strategy, and information technology (5th ed.). New York: McGraw Hill/Irwin.

18. Fixson, S. K. (2005). Product architecture assessment: A tool to link product, process, and supply chain decisions. Journal of Operations Management, 23, 345-369. doi:10.1016/j.jom.2004.08.006.

19. Hasenfeld, Y. (1983). Human service organizations. Englewood Cliffs: Prentice Hall.

20. Herzlinger, R. E. (1998). The managerial revolution in the U.S. health care sector. Health Care Management Review, 23(3), 19-29.

21. Herzlinger, R. E. (2004). Consumer-driven health care. Implications for providers, payers, and policymakers. San Fransisco: Jossey-Bass.

22. Hyer, N. L., Wemmerlov, U., Morris, J., \& Shtub, A. (2003). Cellular manufacturing in health care: The case of a trauma unit. In G. Spina, A. Vinelli, R. Cagliano, M. Kalchschmidt, P. Romano, \& F. Salvador (Eds.), EurOMA conference: One world? One view of OM? Como.

23. Kellogg, D. L., \& Nie, W. (1995). A framework for strategic service management. Journal of Operations Management, 13, 323-337. doi:10.1016/0272-6963(95)00036-4.

24. Kotler, P., Armstrong, G., Saunders, J., \& Wong, V. (1999). Principles of marketing (2nd ed.). London: Prentice Hall Europe.

25. Larsson, R., \& Bowen, D. E. (1989). Organization and customer: managing design and coordination of services. Academy of Management Review, 14(2), 213-233. doi:10.2307/258417.

26. Layton, A., Moss, F., \& Morgan, G. (1998). Mapping out the patient's journey: Experiences of developing pathways of care. Quality in Health Care, 7(supplement), S30-S36.

27. Leichsenring, K., Roth, G., Wolf, M., \& Sissouras, A. (2005). Moments of truth. An overview of pathways to integration and better quality in long-term care. In J. Billings \& K. Leichsenring (Eds.), Integrating health and social care services for older persons (pp. 13-38). Aldershot: Ashgate Publishing.

28. Lengnick-Hall, C. A. (1996). Customer contributions to quality: A different view of the customeroriented firm. Academy of Management Review, 21(3), 791-824. doi:10.2307/259002.

29. Leung, G. M. (2000). Hospitals must become 'focused factories'. British Medical Journal, 320(7239), 942. doi:10.1136/bmj.320.7239.942.

30. Liss, P. E. (1993). Health care need. Meaning and measurement. Aldershot: Avebury.

31. Liss, P. E. (1995). Needs assessment: Handle with care. Health Care Analysis, 3(4), 312-314. doi: 10.1007/BF02197078.

32. Liss, P. E. (2003). The significance of the goal of health care for the setting of priorities. Health Care Analysis, 11(2), 161-169. doi:10.1023/A:1025657130508.

33. Lovelock, C., \& Gummesson, E. (2004). Whither services marketing? In search of a new paradigm and fresh perspectives. Journal of Service Research, 7(1), 20-41. doi:10.1177/1094670504266131.

34. Lovelock, C., \& Young, R. F. (1979). Look to consumers to increase productivity. Harvard Business Review, 57, 168-178.

35. Luijkx, K., \& De Blok, C. (2007). Diversity among the elderly, diversity in approach. In H. Moerbeek, A. Niehof \& J. van Ophem (Eds.), Changing families and their lifestyles. Wageningen: Wageningen Academic Publishers.

36. Luijkx, K., \& Pardoel, K. (2005). Ouderensegmenten. Behoeften wonen, welzijn en zorg in de wijk. Tilburg: IVA.

37. Luijkx, K., De Blok, C., Van den Akker, P., \& Meijboom, B. (2004). Zorgarrangementen in de ouderenzorg. Vraagsturing in zorg en welzijn in Tilburg. Tilburg: IVA/Tranzo.

38. McLaughlin, C. P., \& Kaluzny, A. D. (2000). Building client centered systems of care: Choosing a process direction for the next century. Health Care Management Review, 25(1), 73-82.

39. Mead, N., \& Bower, P. (2000). Patient-centeredness: a conceptual framework and review of the empirical literature. Social Science \& Medicine, 51(7), 1081110. doi:10.1016/S0277-9536(00) 00098-8.

40. Metters, R., \& Vargas, V. (2000). A typology of de-coupling strategies in mixed services. Journal of Operations Management, 18, 663-682. doi:10.1016/S0272-6963(00)00038-3.

41. Meyer, M. H., \& DeTore, A. (1999). Product development for services. Academy of Management Executive, 13(3), 64-76. 
42. Meyer, M. H., \& DeTore, A. (2001). Perspective: Creating a platform-based approach for developing new services. Journal of Product Innovation Management, 18, 188-204. doi:10.1016/S0737-6782 (01)00070-4.

43. Meyer Goldstein, S., Johnston, R., Duffy, J. A., \& Rao, J. (2002). The service concept: The missing link in service design research? Journal of Operations Management, 20, 121-134. doi:10.1016/ S0272-6963(01)00090-0.

44. Putters, K. (2003). Vraagsturing tussen feit en fictie. Stand van zaken in de gezondheidszorg. Beleidswetenschappen, 17(2), 87-98.

45. Raad voor de Volksgezondheid en Zorg. (1998). Naar een meer vraaggerichte zorg. Zoetermeer: RVZ.

46. Rijckmans, M. J. N. (2005). Positioning the Individual in health care. Unpublished doctoral thesis, Tilburg University, Tilburg.

47. Rijckmans, M. J. N., Garretsen, H. F. L., Van de Goor, L. A. M., \& Bongers, I. M. B. (2005). Keyconcepts of demand-driven health care: An approach based on client's needs. Medicine and Law, 24(3), 463-477.

48. Rijckmans, M. J. N., Bongers, I. M. B., Garretsen, H. F. L., \& van de Goor, L. A. M. (2007). A clients' perspective on demand-oriented and demand-driven health care. The International Journal of Social Psychiatry, 53(1), 48-62. doi:10.1177/0020764006074292.

49. Salvador, R., Forza, C., \& Rungtusanatham, M. (2002). Modularity, product variety, production volume, and component sourcing: Theorizing beyond generic prescriptions. Journal of Operations Management, 20, 549-575. doi:10.1016/S0272-6963(02)00027-X.

50. Sampson, S. E., \& Froehle, C. M. (2006). Foundations and implications for a proposed unified services theory. Production and Operations Management, 15(2), 329-343.

51. Sanchez, R. (1999). Modular architectures in the marketing process. Journal of Marketing, 63(special issue), 92-111. doi:10.2307/1252104.

52. Sanchez, R., \& Mahoney, J. T. (1996). Modularity, flexibility, and knowledge management in product and organization design. Strategic Management Journal, 17(Winter special issue), 63-76.

53. Schellekens, A. (2004). Towards flexible programmes in higher professional education. An operations-management approach. Unpublished doctoral thesis, Open University of The Netherlands.

54. Schellingerhout, R. (2008). Ondersteunende voorzieningen. Samenhang tussen AWBZ-gefinancierde zorg en woon-en welzijnsvoorzieningen. Den Haag: Sociaal en Cultureel Planbureau.

55. Schmenner, R. W. (1986). How can service businesses survive and prosper? Sloan Management Review, (Spring), 21-32.

56. Schneider, B. (1993). HRM-A service perspective: Towards a customer-focused HRM. International Journal of Service Industry Management, 5(1), 64-76. doi:10.1108/09564239410051911.

57. Schols, J. M. G. A. (2004). De toekomst van de chronische zorg, ons een zorg? (inaugural lecture). Amsterdam: Dutch University Press.

58. Schoot, T., Proot, I., Ter Meulen, R., \& De Witte, L. (2005). Recognition of client values as a basis for tailored care: The view of Dutch expert patients and family caregivers. Scandinavian Journal of Caring Sciences, 19, 169-176. doi:10.1111/j.1471-6712.2005.00327.x.

59. Schulman, B. A. (1979). Active patient orientation and outcomes in hypertensive treatment. Medical Care, 17(3), 267-280. doi:10.1097/00005650-197903000-00004.

60. Slack, N., Chambers, S., \& Johnston, R. (2007). Operations management (5th ed.). Harlow: Prentice Hall.

61. Sousa, R., \& Voss, C. A. (2001). Quality management: Universal or context dependent? Production and Operations Management, 10(4), 383-404.

62. Starr, M. K. (1965). Modular production-A new concept. Harvard Business Review, 53(NovemberDecember), 131-142.

63. Ulrich, K. (1995). The role of product architecture in the manufacturing firm. Research Policy, 24, 419-440. doi:10.1016/0048-7333(94)00775-3.

64. Van Bilsen, P. M. A. (2007). Care for the elderly. An exploration of perceived needs, demands and service use. Maastricht: Maastricht University.

65. Van der Geest, L. (2005). Blijvende zorg. Economische aspecten van langdurige ouderenzorg. Zoetermeer: Raad voor Volksgezondheid en de Zorg/Nyfer.

66. Van der Grinten, T. E. D. (2000). Sturing door en sturing van de vraag: Kanttekeningen bij vraagsturing in de gezondheidszorg. Beleid en Management, 27(4), 249-255. 
67. Van der Kraan, W. G. M., \& Van der Grinten, T. E. D. (2004). The development of demand-driven care as a new governance concept. NIG Annual Work Conference, https://ep.eur.nl/handle/1765/1758. Rotterdam

68. Van Wijk, K. P. (2007). The service care chain. Unpublished doctoral thesis, Erasmus University Rotterdam, Rotterdam.

69. Verma, R., Thompson, G. M., \& Louviere, J. J. (1999). Configuring service operations in accordance with customer needs and preferences. Journal of Service Research, 1(3), 262-274. doi: $10.1177 / 109467059913007$.

70. Verma, R., McLaughlin, C. P., Johnston, R., \& Youngdahl, W. (2005). Operations management in not-for-profit, public and government services. Charting a new research frontier. Journal of Operations Management, 23, 117-123. doi:10.1016/j.jom.2004.09.001.

71. Verma, R., Youngdahl, W., McLaughlin, C. P., \& Johnston, R. (2006). Innovative operations management applications in not-for-profit, public and government services. Journal of Operations Management, 24, 301-303. doi:10.1016/j.jom.2005.08.001.

72. Vissers, J., \& Beech, R. (2005). Health operations management (1st ed.). Abingdon: Routledge.

73. Ware, T., Matosevic, T., Hardy, B., Knapp, M., Kendall, J., \& Forder, J. (2003). Commissioning care services for older people in England: the view from care managers, users and carers. Ageing and Society, 23, 411-428. doi:10.1017/S0144686X02001137.

74. Wemmerlov, U. (1990). A taxonomy for service processes and its implications for system design. International Journal of Service Industry Management, 1(3), 20-40.

75. Wilmot, S. (2007). A fair range of choice: Justifying maximum patient choice in the British National Health Service. Health Care Analysis, 15(2), 59-72. doi:10.1007/s10728-006-0032-6.

76. Young, T., Brailsford, S., Connell, C., Davies, R., Harper, P., \& Klein, J. H. (2004). Using industrial processes to improve patient care. British Medical Journal, 328, 162-164. doi:10.1136/bmj.328. 7432.162.

77. Zomerdijk, L. G. (2005). Design decisions in the front office-Back office issue. Unpublished doctoral thesis, Groningen University, Groningen.

78. Zomerdijk, L. G., \& De Vries, J. (2007). Structuring front office and back office work in service delivery systems: An empirical study of three design decisions. International Journal of Operations \& Production Management, 27(1), 108-137. doi:10.1108/01443570710714565. 